\title{
Microstructure and Mechanical Properties of Ti-12Mo-8Nb Alloy Hot Swaged and Treated for Orthopedic Applications
}

\author{
Aline Raquel Vieira Nunes ${ }^{*}$, Sinara Borborema Gabriel ${ }^{b}$ Carlos Angelo Nunes ${ }^{c}$, Leonardo Sales

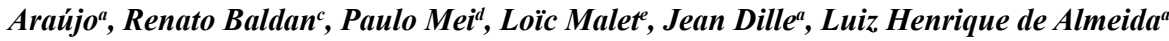 \\ ${ }^{a}$ Universidade Federal do Rio de Janeiro, Rio de Janeiro, RJ, 21.941-972, Brazil \\ ${ }^{b}$ Centro Universitário de Volta Redonda, Volta Redonda, RJ, Brazil \\ ${ }^{c}$ Universidade Estadual Paulista (Unesp), Campus de Itapeva, Itapeva, SP, Brazil \\ ${ }^{d}$ Universidade Estadual de Campinas, Campinas, SP, Brazil \\ 'Université Libre de Bruxelles, Brussels, Belgium
}

Received: December 19, 2016; Revised: July 11, 2017; Accepted: October 05, 2017

\begin{abstract}
Metastable $\beta$-type Ti alloys with non-toxic addition elements such as $\mathrm{Mo}, \mathrm{Zr}$, Sn, Ta and $\mathrm{Nb}$ were developed as an alternative to the widely used Ti-6Al-4V alloy for biomedical applications. These alloys possess enhanced biocompatibility and reduced elastic modulus in comparison with Ti-6Al4V. Moreover, for orthopedic implants, low Young's modulus is required in order to avoid the stress shielding phenomenon. This study analyzes the microstructure and mechanical properties of a new Ti-12Mo-8 $\mathrm{Nb}$ alloy after hot swaging, annealing at $950{ }^{\circ} \mathrm{C}$ for $1 \mathrm{~h}$ and water quenching. The alloy was characterized by X-ray diffraction, optical microscopy and transmission electron microscopy. Tensile tests were performed at room temperature. Young's modulus and hardness values were also measured. The structural characterization reveals a metastable $\beta$ structure containing only a small amount of $\alpha$ and $\omega$ phases. Exhibiting a lower Young's modulus than Ti-6Al-4V and other previously studied Ti-Mo-Nb alloys, the Ti-12Mo-8Nb alloy can be a promising alternative for orthopedic application.
\end{abstract}

Keywords: Titanium alloys, Microstructure, Properties, Orthopedic applications

\section{Introduction}

Titanium and its alloys are increasingly used as orthopedic implants due to superior biocompatibility, lower density and lower Young's modulus in comparison with other metallic biomaterials such as stainless steels or Co-Cr based alloys ${ }^{1-4}$. A low value of Young's modulus is required in order to minimize the modulus mismatch between implant and human bone. This stiffness mismatch can induce the stress shielding phenomenon. Stress shielding occurs where the metal carries a majority of applied load, leaving the more compliant tissue almost unstressed. This will result in a form of osteoporosis around the implant site ${ }^{5}$.

For orthopedic applications, the most widely used $\mathrm{Ti}$ alloy is the Ti-6Al-4V alloy, initially designed for aerospace applications ${ }^{6}$. But the literature indicates that long term health problems would be associated with the release of $\mathrm{Al}$ and $\mathrm{V}$ ions from the Ti-6Al-4V metallic implants into the human body. Aluminum ions increase the potential for the development of Alzeimer's disease whereas vanadium ions into tissues can alter the kinetics of the enzyme activity associated with the inflammatory response cells ${ }^{7}$. Eisenbarth et al. mention, on the other hand, that vanadium is toxic both in elemental form and as oxides ${ }^{8}$.

Therefore, a number of studies have focused on the development of metastable $\beta$-type Ti alloys with non-toxic elements such as $\mathrm{Mo}, \mathrm{Zr}$, Sn, Ta and $\mathrm{Nb}^{9-16}$. In addition to an excellent corrosion resistance in human body fluids, metastable $\beta$-type titanium alloys exhibit lower Young's modulus and better toughness than $\alpha$ and $\alpha+\beta$ alloys. Typical mechanical properties of conventional metallic biomaterials and $\beta$-type Ti alloys are shown in Table $1^{11}$.

Several authors propose different $\beta$-type Ti-Mo-Nb alloys as good candidates for orthopedic implants based on their good mechanical properties and excellent corrosion resistance in solutions simulating the body fluid ${ }^{17-19}$. Moreover, a recent in vitro research demonstrates the very good biocompatibility of Ti-Mo-Nb alloys ${ }^{20}$. In particular, Gabriel et al. have shown that the Ti-12Mo-13Nb $\mathrm{Nb}^{21,22}$ and Ti-10Mo-20 $\mathrm{Nb}^{23,24}$ alloys, aged at $500^{\circ} \mathrm{C}$ after cold or hot swaging, present higher yield strength/elastic modulus ratio and higher hardness/ elastic modulus ratio compared to commercially Ti-6Al$4 \mathrm{~V}$, indicating a great potential for biomedical application.

This study analyzes the microstructure and mechanical properties of a new Ti-12Mo-8 $\mathrm{Nb}$ alloy after hot swaging, annealing at $950^{\circ} \mathrm{C}$ for $1 \mathrm{~h}$ and water quenching. The objective is to investigate if this alloy can also be considered as a good substitute to the Ti-6Al-4V alloy. Moreover, the Ti-12Mo- $8 \mathrm{Nb}$ alloy has a lower content of expensive and heavy $\beta$-stabilizers than the two previously studied Ti-13Mo- $12 \mathrm{Nb}$ and Ti$10 \mathrm{Mo}-20 \mathrm{Nb}$ alloys. For this reason, this new alloy would 
Table 1. Mechanical properties of typical biomaterials ${ }^{11}$.

\begin{tabular}{lcccc}
\hline Alloy & YM & YS & $\begin{array}{c}\text { Strength-to-modulus ratio } \\
\left(\mathbf{\times 1 0} \mathbf{- 1}^{-3}\right.\end{array}$ & $\begin{array}{c}\text { EL } \\
\mathbf{( \% )}\end{array}$ \\
\hline 316 (stainless steel) & 379 & 793 & 2.1 & 22 \\
ASTM F75 (Co-Cr-Mo) & 220 & 448 & 2.0 & 8 \\
Ti (cp) & $103-104$ & $170-485$ & $1.6-4.7$ & $15-24$ \\
Ti-6Al-4V & 124 & 896 & 7.2 & $13-16$ \\
Ti-50Ta (aged) & 77 & 612 & 7.9 & 11.6 \\
Ti-13Nb-13Zr (aged) & $79-84$ & $836-908$ & $10-11.5$ & $6-10$ \\
Ti-15Mo (annealed) & 78 & 544 & 7.0 & 21 \\
\hline
\end{tabular}

be a promising alternative for biomedical application: it will permit to obtain lighter orthopedic implants at lower cost.

\section{Material and Methods}

\subsection{Material Preparation}

The Ti-12Mo-8Nb (wt.\%) alloy was prepared from commercially pure Ti (ASTM F67), Mo (>99.9\%, Plansee Group, Austria) and $\mathrm{Nb}(>99.9 \%$, EEL/USP, Brazil) by arc melting furnace with a tungsten electrode on a watercooled copper hearth. This alloy was prepared in a high purity argon atmosphere ( $>99.9999 \%$ pure) and was then re-melted five times to improve chemical homogeneity. The ingot $(40 \mathrm{~g})$ was then hot swaged at $780-860^{\circ} \mathrm{C}$ to obtain an area reduction of $80 \%$. The hot swaged material (cylindrical in shape) was then annealed at $950{ }^{\circ} \mathrm{C}$ under high vacuum for $1 \mathrm{~h}$ in a tubular furnace, followed by water quenching at room temperature. For Ti- $12 \mathrm{Mo}-8 \mathrm{Nb}, 950^{\circ} \mathrm{C}$ is situated inside the stability domain of $\beta$ phase.

\subsection{Phase Characterization}

Phase characterization was carried out using X-ray diffraction (XRD, Shimadzu model XRD 6000 diffractometer) operated at $40 \mathrm{kV}$ and $30 \mathrm{~mA}$, using $\mathrm{Cu} \mathrm{K}_{\alpha}$ radiation $(\lambda=$ $1.5418 \AA$ ). The phases were identified through comparison with simulated diffraction patterns using the program Powdercell ${ }^{25}$, inserting data of $\alpha, \omega$ and $\beta$-Ti phases as space groups, lattice parameters and atomic positions ${ }^{26}$.

The microstructure of the alloy was investigated by optical microscopy (OM). The sample was ground using silicon carbide papers up to 2400 mesh, polished using standard metallographic techniques and then etched with Kroll's reagent ( $3 \mathrm{~mL} \mathrm{HF}, 6 \mathrm{~mL} \mathrm{HNO}_{3}$ and $100 \mathrm{~mL} \mathrm{H}_{2} \mathrm{O}$ ).

The microstructure of the alloy was also investigated by transmission electron microscopy (TEM) using a Philips CM20 transmission electron microscope operated at $200 \mathrm{kV}$. The thin foils were prepared using a twin-jet electropolishing equipment in a solution containing $(60 \mathrm{~mL}) \mathrm{HClO}_{4},(590$ $\mathrm{mL})$ methanol, and $(350 \mathrm{~mL})$ ether monobutylethylene at $35 \mathrm{~V}$ and $-20^{\circ} \mathrm{C}$.

\subsection{Measurement of mechanical properties}

The Vickers microhardness values were measured by using a DHV-1000 Micro Vickers Hardness Tester with a $300 \mathrm{gf}$ load for $15 \mathrm{~s}$. The Vickers microhardness value of a given alloy is the average of ten measurements.

The Young's modulus (YM) was determined by ultrasonicpulse method according to the ASTM E 494-95 standard $^{27}$. Five measurements were performed for each sample.

Tensile tests were performed at room temperature with specimens with $24 \mathrm{~mm}$ in length and $4 \mathrm{~mm}$ in diameter and using a strain rate of $4 \times 10^{-3} \mathrm{~s}^{-1}$. From the stress-strain curves, the yield strength (YS), the ultimate tensile strength (UTS) and the elongation at rupture (EL) can be determined. Two specimens were tested to rupture and the mean value of each property was calculated.

\section{Results and Discussion}

\subsection{Microstructural Characterization}

Figure 1 presents the XRD pattern of the Ti-12Mo- $8 \mathrm{Nb}$ alloy hot swaged, annealed at $950{ }^{\circ} \mathrm{C}$ for $1 \mathrm{~h}$ and water quenched. The $\beta$ single phase can be identified. However, a weak reflection from $\alpha$ phase is observed (for $2 \theta=35^{\circ}$ ). For this alloy, this reflection was unexpected. Indeed, the calculated value of the $\beta$-stabilizer equivalence $[\mathrm{wt} \% \mathrm{Mo}$ ] eq for the Ti-12Mo-8Nb alloy is 14.24 . When [ $\left.\mathrm{wt}_{\mathrm{t}} \% \mathrm{Mo}\right]_{\mathrm{eq}}$ is higher than 10 , the presence of $\alpha$ phase is not foreseen.

The optical micrograph depicted in Figure 2 shows a monophased microstructure with equiaxial $\beta$ grains. $\alpha$ phase is not detected by optical microscopy.

Figures 3(a) and 3(b) are TEM bright field images of the Ti-12Mo-8 $\mathrm{Nb}$ alloy hot swaged, annealed at $950{ }^{\circ} \mathrm{C}$ for $1 \mathrm{~h}$ and water quenched. Figure 3(a) reveals a small volume fraction of $\alpha$ phase inside the $\beta$ matrix. This observation confirms the XRD results, indicating the presence of a small amount of $\alpha$ phase. On figure 3(b), a few nanosized precipitates (in black) are detected. The selected area electron diffraction (SAED) pattern of the region corresponding to figure 3(b) is indexed on figure 3(c). The indexation permits to identify these precipitates as athermal $\omega$ precipitates inside 


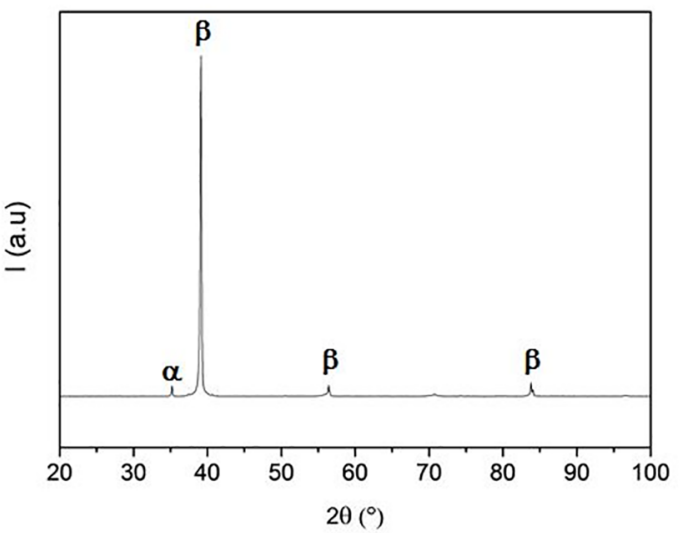

Figure 1. XRD pattern of Ti-12Mo- $8 \mathrm{Nb}$ alloy hot swaged, annealed at $950^{\circ} \mathrm{C} / 1 \mathrm{~h}$ and water quenched.

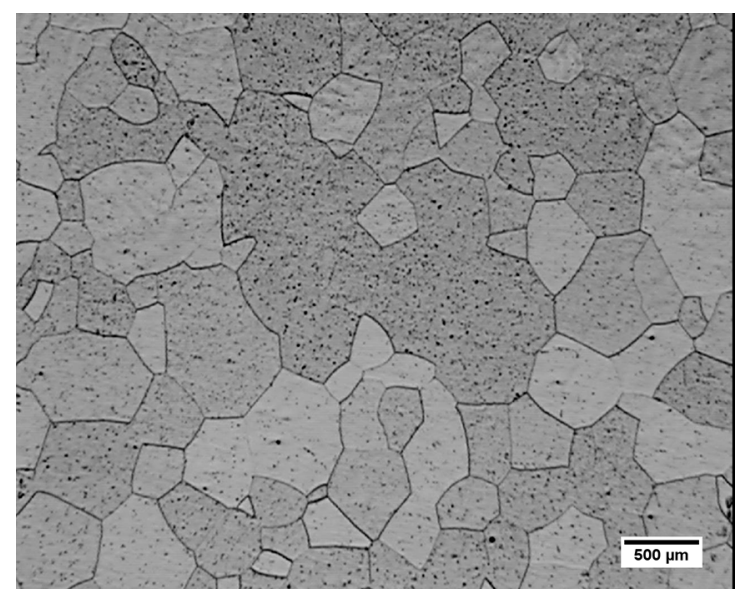

Figure 2. OM of Ti-12Mo- $8 \mathrm{Nb}$ alloy hot swaged, annealed at $950^{\circ} \mathrm{C} / 1 \mathrm{~h}$ and water quenched.
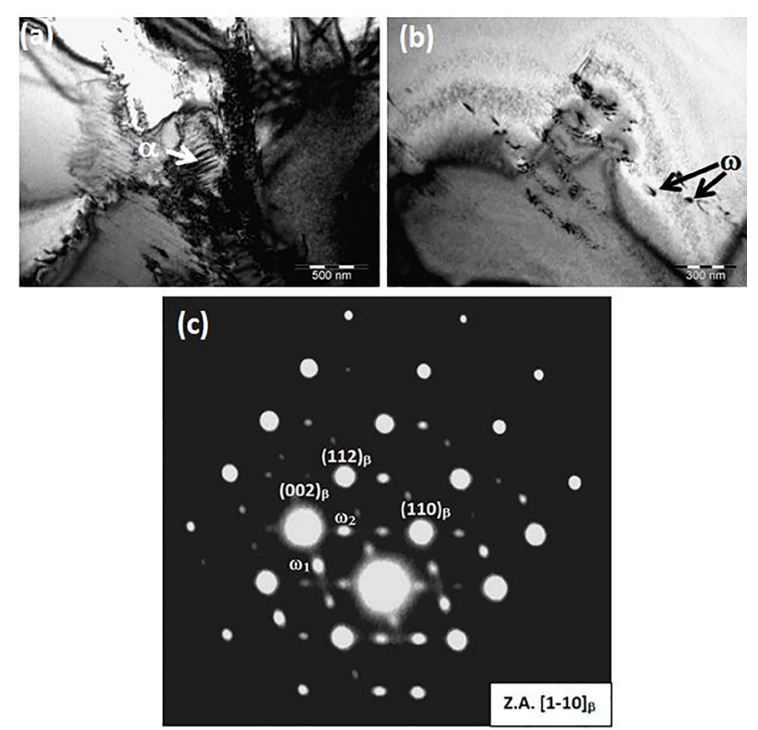

Figure 3. TEM analysis of Ti-12Mo-8 $\mathrm{Nb}$ alloy hot swaged, annealed at $950^{\circ} \mathrm{C} / 1 \mathrm{~h}$ and water quenched: (a) bright-field $\alpha$ phase precipitation in a $\beta$ matrix; (b) bright-field image showing $\omega$ precipitates in a matrix; (c) selected area electron diffraction pattern of region $3 \mathrm{~b}$. the $\beta$ matrix. Indeed, the pattern in figure 3(c) corresponds to the $\beta$ phase diffraction pattern from the $[110]_{\beta}$ zone axis and additional reflections appear at $1 / 3$ and $2 / 3\{112\}_{\beta}$ reflections. The positions of these reflections are consistent with those expected from the hexagonal $\omega$ phase which has the crystallographic orientation relationship ${ }^{28}$ :

$(0001)_{\omega} / /(111)_{\beta} ;[11-20]_{\omega} / /[1-10]_{\beta}$

On the diffraction pattern and according to the zone axis, two $\omega$ variants are distinguished $\left(\omega_{1}\right.$ and $\left.\omega_{2}\right)$. Although $\omega$ precipitates are unambiguously identified by electron diffraction, no evidence of $\omega$ phase precipitation is observed in the XRD pattern. This can be due to its too low volume fraction inside the $\beta$ matrix.

In conclusion, the microstructure of Ti-12Mo- $8 \mathrm{Nb}$ alloy hot swaged, annealed at $950^{\circ} \mathrm{C}$ for $1 \mathrm{~h}$ and water quenched, consists almost entirely of equiaxial $\beta$ grains. The quench from the $\beta$ phase stability domain permits to keep a metastable $\beta$ structure at room temperature, with only a small amount of $\alpha$ and $\omega$ phases.

\subsection{Mechanical Characterization}

The mechanical properties measured in this study on Ti-12Mo-8Nb alloy, hot swaged, heat treated for $1 \mathrm{~h}$ at $950^{\circ} \mathrm{C}$ and water quenched are summarized in Table 2 . This table contents also the mechanical properties measured in previous studies $^{22,24}$ on Ti-6Al-4V, Ti-12Mo-13Nb and Ti$10 \mathrm{Mo}-20 \mathrm{Nb}$. The two last alloys were hot swaged and aged for $4 \mathrm{~h}$ at $500^{\circ} \mathrm{C}$.

In addition to contain non-toxic and allergy free elements, Ti-Mo-Nb alloys have another advantage over Ti-6Al-4V alloy: a lower Young's modulus. Reducing stiffness mismatch between implant and bone is essential in order to avoid the stress shielding phenomenon. Table 2 indicates that Ti-13Mo$12 \mathrm{Nb}$, Ti- $10 \mathrm{Mo}-20 \mathrm{Nb}$ and Ti- $12 \mathrm{Mo}-8 \mathrm{Nb}$ alloys present a reduction in Young's modulus of, respectively, 21\%, 24\% and $35 \%$ in comparison with Ti-6Al-4V alloy. The lower Young's modulus of the Ti-Mo-Nb alloys can mainly be attributed to the $\mathrm{Mo}$ and $\mathrm{Nb}$ atoms in solid solution. Niobium and molybdenum have high solubility in titanium but also larger atomic radius. The calculated atomic radius is 248 $\mathrm{pm}$ for Ti whereas it is $320 \mathrm{pm}$ for $\mathrm{Nb}$ and $306 \mathrm{pm}$ for Mo. At the contrary, the atomic radii of $\mathrm{Al}$ and $\mathrm{V}$ are smaller, respectively $118 \mathrm{pm}$ for $\mathrm{Al}$ and $171 \mathrm{pm}$ for $\mathrm{V}^{29}$. Liu et al. have shown that a decrease of Young's modulus is associated with the presence of larger substitutional atoms inside the Ti lattice ${ }^{30}$. This presence reduces the binding force of the lattice by expanding unit cell volume.

Amongst the three considered Ti-Mo-Nb alloys, the lowest Young modulus value corresponds to the Ti-12Mo$8 \mathrm{Nb}$ alloy. This can be attributed to its microstructure. $\beta$-type titanium alloys exhibit lower Young's modulus than $(\alpha+\beta)$ or $(\beta+\omega)$ alloys ${ }^{31}$. The previously studied Ti- $13 \mathrm{Mo}-12 \mathrm{Nb}$ and Ti-10Mo-20 $\mathrm{Nb}$ alloys, aged for $4 \mathrm{~h}$ at $500^{\circ} \mathrm{C}$, present a bi-phased $(\alpha+\beta)$ microstructure. On the other hand, the very low volume fractions of $\alpha$ phase and $\omega$ precipitates in 
Table 2. Mechanical properties of Ti-6Al-4V, Ti-13Mo-12Nb, Ti-10Mo-20Nb and Ti-12Mo-8Nb alloys.

\begin{tabular}{|c|c|c|c|c|c|c|c|}
\hline Alloy & $\begin{array}{c}\text { YM } \\
(\mathbf{G P a})\end{array}$ & $\begin{array}{c}\text { H } \\
(\mathbf{H V})\end{array}$ & $\begin{array}{c}\text { YS } \\
(\mathrm{MPa})\end{array}$ & $\begin{array}{l}\text { UTS } \\
\text { (MPa) }\end{array}$ & $\begin{array}{l}\text { HV to } \\
\text { YM ratio }\end{array}$ & $\begin{array}{l}\text { EL } \\
(\%)\end{array}$ & Ref. \\
\hline Ti-6Al-4V & $140 \pm 3.7$ & $337 \pm 16$ & 930 & 966 & 2.40 & 14.2 & 22 \\
\hline $\begin{array}{l}\text { Ti-13Mo-12Nb } \\
\text { (hot swaged }+ \text { aged } 4 \mathrm{~h} \text { at } 500^{\circ} \mathrm{C} \text { ) }\end{array}$ & $110 \pm 2.6$ & - & 981 & 1111 & - & 6.3 & 22 \\
\hline $\begin{array}{l}\text { Ti-10Mo-20Nb } \\
\left.\text { (hot swaged }+ \text { aged } 4 \mathrm{~h} \text { at } 500^{\circ} \mathrm{C}\right)\end{array}$ & $106.1 \pm 1.3$ & $245 \pm 10$ & - & - & 2.31 & - & 24 \\
\hline $\begin{array}{l}\text { Ti-12Mo-8Nb } \\
\text { (hot swaged + annealed } 1 \mathrm{~h} \text { at } 950^{\circ} \mathrm{C} \text { ) }\end{array}$ & $91 \pm 0.53$ & $275 \pm 9$ & 528 & 716 & 3.03 & 33 & $\begin{array}{l}\text { This } \\
\text { work }\end{array}$ \\
\hline
\end{tabular}

the Ti-12Mo- $8 \mathrm{Nb}$ alloy do not have any significant influence on Young's modulus value.

Figure 4 shows the stress-strain curves at room temperature for the Ti-12Mo- $8 \mathrm{Nb}$ alloys and indicates the mean values of yield strength (YS), ultimate tensile strength (UTS) and elongation at rupture (EL) measured from these curves.

Comparing these values to the values measured for other alloys mentioned in Table 2 and exhibiting a bi-phased ( $\alpha$ $+\beta$ ) microstructure, the monophased $\mathrm{Ti}-12 \mathrm{Mo}-8 \mathrm{Nb}$ alloy has a lower yield strength and ultimate tensile strength but a higher ductility characterized by its elongation at rupture. The explanation is that these properties strongly depend on the microstructure. With less slip systems available, the plastic deformation is more difficult for HCP $\alpha$ phase than for BCC $\beta$ phase $^{32}$. Therefore, $(\alpha+\beta)$ Ti alloys present higher strength and lower ductility than $\beta$ Ti alloys. Moreover, the literature mentions the strengthening effect of $\omega$ precipitation in $\beta$ matrix $^{33}$. But, due to the low volume fraction of $\omega$ precipitates, it can be assumed that this hardening is very limited in the Ti-12Mo- $8 \mathrm{Nb}$ alloy annealed for $1 \mathrm{~h}$ at $950^{\circ} \mathrm{C}$.

Table 2 also contents the hardness values. As a general rule, an increase in hardness decreases the incidence of wear on implant material ${ }^{34}$. Ti-6Al-4V exhibits the highest hardness value. On the other hand, the hardness of annealed Ti-12Mo- $8 \mathrm{Nb}$ alloy is slightly higher than the hardness of

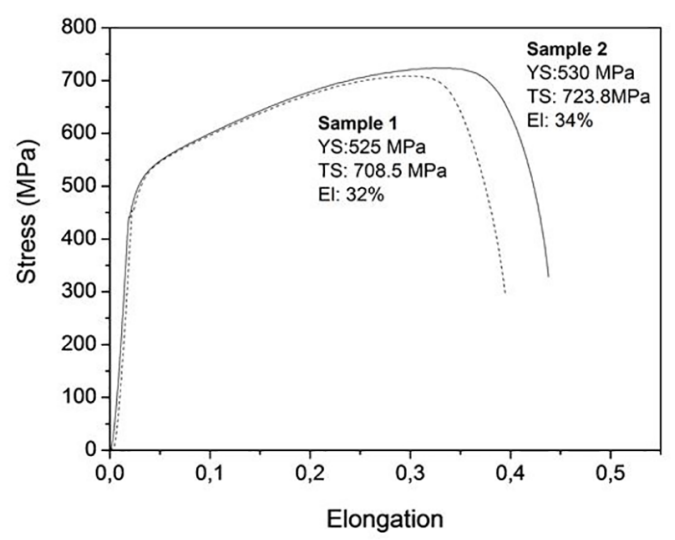

Figure 4. Stress-strain curves of Ti- $12 \mathrm{Mo}-8 \mathrm{Nb}$ alloy at room temperature. aged Ti-20Mo-10Nb. The two alloys have simultaneously different chemical compositions and microstructures. This does not allow a correlation between these chemical or structural differences and the measured hardness variation. For $\beta$ monophased Ti-Mo-Nb alloys, $\mathrm{Xu}$ et al. showed an increase in hardness with decreasing $\mathrm{Nb}$ content but these authors did not justify this behavior ${ }^{17,18}$. In a previous work, Gabriel $^{35}$ measured a $255 \mathrm{HV}$ hardness value for Ti-12Mo$13 \mathrm{Nb}$ annealed for $1 \mathrm{~h}$ at $950^{\circ} \mathrm{C}$ whereas the Ti- $12 \mathrm{Mo}-8 \mathrm{Nb}$ alloy annealed in the same conditions exhibits a $275 \mathrm{HV}$ hardness value. These results are compatible with the studies of $\mathrm{Xu}$ et al. For both Ti-12Mo-8Nb and Ti-12Mo-13Nb alloys, XRD pattern shows only the presence of $\beta$ phase. On the other hand, TEM analysis reveals $\omega$ precipitation in Ti-12Mo- $8 \mathrm{Nb}$ but not in Ti-12Mo-13Nb. This difference may be attributed to the $\beta$-stabilizer role of niobium in Ti alloys. $\omega$ precipitation hardening can explain the higher hardness of Ti-12Mo- $8 \mathrm{Nb}$ in comparison with Ti-12Mo-13Nb. The XRD patterns obtained by Xu et al. only reveal the BCC $\beta$ phase for all $\mathrm{Nb}$ contents. These authors did not perform TEM analysis. It could be possible that the presence of a small volume fraction of. $\omega$ precipitates, only detectable by TEM, in their alloys with low $\mathrm{Nb}$ contents induces the observed increase in hardness when $\mathrm{Nb}$ content decreases.

For metallic materials, lower Young's modulus generally corresponds also to lower hardness. Therefore, it is necessary to find the best compromise between these mechanical properties. Hardness to Young's modulus ratio is often used as key indicator in order to evaluate the mechanical performance of metallic biomaterials for implant applications ${ }^{22}$. Higher is the ratio, more appropriate is the material. Ti- $12 \mathrm{Mo}-8 \mathrm{Nb}$ presents the highest hardness to Young's modulus ratio amongst the Ti alloys presented in Table 2.

\section{Conclusions}

The structural characterization indicates that the Ti-12Mo$8 \mathrm{Nb}$ alloy, hot swaged, annealed for $1 \mathrm{~h}$ at $950^{\circ} \mathrm{C}$ and water quenched, presents a metastable $\beta$ structure containing only a small amount of $\alpha$ and $\omega$ phases. This structure confers to this alloy a lower Young's modulus in comparison with other alloys mentioned in Table 2 , which exhibit a bi-phased ( $\alpha$ 
$+\beta)$ microstructure. In addition, it also presents the highest hardness to Young's modulus ratio.

The results show that $\mathrm{Ti}-12 \mathrm{Mo}-8 \mathrm{Nb}$ alloy can be a promising alternative to Ti-6Al-4V for biomedical applications. Furthermore, this alloy is competitive compared to the previously studied Ti-12Mo-13 Nb and Ti-20Mo-10Nb alloys, permitting to obtain lighter orthopedic implants at lower cost.

\section{Acknowledgements}

This work was supported by CNPq, FAPERJ and CAPES. One co-author is grateful to $\mathrm{CNPq}$ for his visiting researcher grant.

\section{References}

1. Long M, Rack HJ. Titanium alloys in total joint replacement-a materials science perspective. Biomaterials. 1998;19(18):16211639.

2. Geetha M, Singh AK, Asokamani R, Gogia AK. Ti based biomaterials, the ultimate choice for orthopaedic implants - A review. Progress in Materials Science. 2009;54(3):397-425.

3. Chen Q, Thouas GA. Metallic implant biomaterials. Materials Science and Engineering R. 2015;87:1-57.

4. Rack HJ, Qazi JI. Titanium alloys for biomedical applications. Materials Science and Engineering: C. 2006;26(8):1269-1277.

5. Li Y, Yang C, Zhao H, Qu S, Li X, Li YY. New developments of Ti-based alloys for biomedical applications. Materials. 2014;7(3):1709-1800.

6. Niinomi M. Mechanical properties of biomedical titanium alloys. Materials Science and Engineering: A. 1998;243(1-2):231-236.

7. Mohammed MT, Khan ZA, Siddiquee AN. Beta Titanium Alloys: The Lowest Elastic Modulus for Biomedical Applications: A Review. International Journal of Chemical, Nuclear, Materials and Metallurgical Engineering. 2014;8(8):726-731.

8. Eisenbarth E, Velten D, Müller M, Thull R, Breme J. Biocompatibility of beta-stabilizing elements of titanium alloys. Biomaterials. 2004;25(26):5705-5713.

9. Kuroda D, Niinomi M, Morinaga M, Kato Y, Yashiro T. Design and mechanical properties of new $\beta$ type titanium alloys for implant materials. Materials Science and Engineering: $A$. 1998;243(1-2):244-249.

10. Guo S, Meng QK, Cheng XN, Zhao XQ. Deformation behavior of metastable $\beta$-type Ti-25Nb-2Mo-4Sn alloy for biomedical applications. Journal of the Mechanical Behavior of Biomedical Materials. 2014;38:26-32.

11. Zhou YL, Niinomi M. Microstructures and mechanical properties of Ti-50mass\% Ta alloy for biomedical applications. Journal of Alloys and Compounds. 2008;466(1-2):535-542.

12. Nnamchi PS, Obayi CS, Todd I, Rainforth MW. Mechanical and electrochemical characterisation of new Ti-Mo-Nb-Zr alloys for biomedical applications. Journal of the Mechanical Behavior of Biomedical Materials. 2016;60:68-77.
13. Jung TK, Semboshi S, Masahashi N, Hanada S. Mechanical properties and microstructures of $\beta \mathrm{Ti}-25 \mathrm{Nb}-11 \mathrm{Sn}$ ternary alloy for biomedical applications. Materials Science and Engineering: C. 2013;33(3):1629-1635.

14. Qazi JI, Rack HJ. Metastable Titanium Alloys for Orthopedic Applications. Advanced Engineering Materials. 2005;7(11):993998.

15. Ferrandini PL, Cardoso FF, Souza SA, Afonso CR, Caram R. Aging response of the Ni-35Nb-7Zr-5Ta and Ti-35Nb-7Ta alloys. Journal of Alloys and Compounds. 2007;433(1-2):207-210.

16. Moraes PEL, Contieri RJ, Lopes ESN, Robin A, Caram R. Effect of Sn addition on the microstructure, mechanical properties and corrosion behavior of Ti-Nb-Sn alloys. Materials Characterization. 2014;96:273-281.

17. Xu LJ, Xiao SL, Tian J, Chen YY. Microstructure, mechanical properties and dry wear resistance of $\beta$-type Ti- $15 \mathrm{Mo}-\mathrm{xNb}$ alloys for biomedical applications. Transactions of Nonferrous Metals Society of China. 2013;23(3):692-698.

18. Xu LJ, Chen YY, Liu ZG, Kong FT. The microstructure and properties of $\mathrm{Ti}-\mathrm{Mo}-\mathrm{Nb}$ alloys for biomedical application. Journal of Alloys and Compounds. 2008;453(1-2):320-324.

19. Chelariu R, Bolat G, Izquierdo J, Mareci D, Gordin DM, Gloriant T, et al. Metastable beta Ti-Nb-Mo alloys with improved corrosion resistance in saline solution. Electrochemica Acta. 2014;137:280-289.

20. Neascu P, Gordin DM, Mitran V, Gloriant T, Costache M, Cumpean V. In vitro performance assessment of new beta TiMo-Nb alloy compositions. Materials Science and Engineering: C. 2015;47:105-113.

21. Gabriel SB, de Almeida LH, Nunes CA, Dille J, Soares GA. Maximisation of the ratio of microhardness to the Young's modulus of Ti-12Mo-13Nb alloy through microstructure changes. Materials Science and Engineering: C. 2013;33(6):3319-3324.

22. Gabriel SB, Dille J, Rezende MC, Mei P, de Almeida LH, Baldan $\mathrm{R}$, et al. Mechanical Characterization of Ti-12Mo-13Nb Alloy for Biomedical Application Hot Swaged and Aged. Materials Research. 2015;18(Suppl. 2):8-12.

23. Gabriel SB, Rezende MC, de Almeida LH, Nunes CA, Dille J, Soares GA. Control of the Microhardness to Young Modulus Ratio by Mechanical Processing of a Ti-10Mo-20Nb Alloy. Materials Research. 2015;18(Suppl. 2):39-42.

24. Gabriel SB, Dille J, Nunes CA, Santos Junior E, Baldan R, Mei P, et al. Effect of Hot Swaging on Microstructure and Properties of Aged Ti-10Mo-20Nb Alloy. Materials Science Forum. 2016;869:952-956.

25. Kraus W, Nolze GJ. POWDER CELL: a program for the representation and manipulation of crystal structures and calculation of the resulting X-ray powder patterns. Journal of Applied Crystallography. 1996;29(3):301-303.

26. Villars P, Calvert LD. Pearson's Handbook of Crystallographic Data for Intermetallic Phases. $2^{\text {nd }}$ ed. Materials Park: ASM International; 1991.

27. ASTM International. ASTM E494-95 - Standard Practice for Measuring Ultrasonic Velocity in Materials. West Conshohocken: ASTM International; 1995. 
28. De Fontaine D, Paton NE, Williams JC. The omega phase transformation in titanium alloys as an example of displacement controlled reactions. Acta Metallurgica. 1971;19(11):1153-1162.

29. Ghosh DC, Biswas R. Theoretical Calculation of Absolute Radii of Atoms and Ions. Part 1. The Atomic Radii. International Journal of Molecular Sciences. 2002;3(2):87-113.

30. Liu Q, Meng Q, Guo S, Zhao X. $\alpha^{\prime}$ Type Ti-Nb-Zr alloys with ultra-low Young's modulus and high strength. Progress in Natural Science: Materials International. 2013;23(6):562-565.

31. Niimoni M, Hattori T, Morikawa K, Kasuga T, Suzuki A, Fukui H, et al. Development of Low Rigidity $\beta$-type Titanium Alloy for Biomedical Applications. Materials Transactions. 2002;43(12):2970-2977.
32. Froes FH. Titanium: Physical Metallurgy, Processing, and Applications. Materials Park: ASM International; 2015. 404 p.

33. Li C, Lee DG, Mi X, Ye W, Hui S, Lee Y. Effect of Al Addition on $\omega$ Precipitation and Age Hardening of Ti-Al-Mo-Fe Alloys. Metallurgical and Materials Transactions A. 2016;47(5):24542461.

34. Saini M, Singh Y, Arora P, Arora V, Jain K. Implant biomaterials: A comprehensive review. World Journal of Clinical Cases. 2015;3(1):52-57.

35. Gabriel SB. Processamento e caracterização de ligas Ti-Mo- $\mathrm{Nb}$ para aplicações biomédicas. [Thesis]. Rio de Janeiro: COPPE/ UFRJ; 2008. 